\title{
HAKIKAT TAFSIR ISRAILIYYAT DALAM PENAFSIRAN AL-QUR'AN
}

\author{
Oleh: Hawirah ${ }^{1}$ \\ ${ }^{1}$ Institut Agama Islam Muhammadiyah Sinjai, \\ Jl. Sultan Hasanuddin, No. 20 Balangnipa, Sinjai \\ E-Mail: hawirahgmail.com, Tlp.: +6285299951322
}

\begin{abstract}
Abstrak
Al-Qur'an sebagai petunjuk, tentunya al-Qur'an harus dipahami, dihayati dan diamalkan oleh manusia yang beriman, namun kenyataannya tidak semua orang bisa dengan mudah memahami al-Qur'an, bahkan sahabat-sahabat Nabi sekalipun yang secara umum menyaksikan turunnya wahyu dan mengetahui konteksnya, serta memahami secara alamiah struktur bahasa dan kosa katanya. Maka dari itu perlunta tafsir untuk menerjemahkan dan mengkaji makna dari al-quran agar tidak ada kesalahan dalam penafsiran. Misal penafsiran riwayat israiliyyat, demi memngetahui dan membedakan penafsiran yang benar. Pengaruh riwayat tafsiran israiliyyat terhadap ilmu tafsir adalah untuk memahami al-Qur'an. Karena itu tafsir al-Qur'an mempunyai peranan yang sangat besar. Namun,ilmu tersebut akan menjadi sesuatu yang tidak berharga lagi ketika terkontaminasi dengan hal yang merusak keabsahan dan kebenarannya,dan akan merusak bagi kalangan yang awam yang tidak mengetahuinya. Masuknya israiliyyat dalam tafsir tidak terlepas dari kondisi sosio kultrul masyarakat arab. Israiliyyat mengandung dua arti, kisah dan dongeng yang disusupkan dalam tafsir dan hadits yang asal periwayatannya kembali kepada sumbernya yaitu Yahudi, Nashrani dan yang lainnya.
\end{abstract}

Kata Kunci: Tafsir, Hadis, Israiliyyat

\section{PENDAHULUAN}

$\mathrm{P}$ ada masa Rasulullah Saw. hidup, umat Islam tidak menemukan kesulitan dalam memahami petunjuk urusan dalam kehidupan mereka, karena ketika muncul permasalahan atu kesulitan dalam ayat-ayat al-Qur'an, mereka akan langsung bertanya kepada Rasulullah Saw. dan kemudian kemudian Rasulullah menjelaskan maksud kandungan ayat tersebut.

Sepeninggalan Rasulullah Saw, meskipun umat islam pada saat itu menegetahui bahasa Arab, namun mereka banyak menemukan kesulitan karena al-Qur'an terkadang isyarat-isyarat yang belum bisa dijangkau oleh pikiran orang-orang Arab. Oleh karena itu mereka membutuhkan tafsir yang bisa membimbing dan menghantarkan mereka untuk memahami isyarat-isyarat seperti itu.

Teks al-Qur'an adalah wahyu Allah yang tidak akan berubah oleh campur tangan manusia, tapi pemahaman terhadap al-Qur'an tidak tetap, selalu berubah sesuai dengan kemampuan orang yang memahami isi kandungan al-Qur'an itu dalam rangka mengaktualkannya dalam bentuk konsep yang bisa dilaksanakan. Dan ini akan terus berkembang sejalan tuntutan dan permasalahan hidup yang dihadapi manusia, maka di sinilah celah-celah bagi orang-orang yang ingin menghancurkan agama Islam berperan.

Sebagai petunjuk, tentunya al-Qur'an harus dipahami, dihayati dan diamalkan oleh manusia yang beriman, namun kenyataannya tidak semua orang bisa dengan mudah memahami al-Qur'an, 
bahkan sahabat-sahabat Nabi sekalipun yang secara umum menyaksikan turunnya wahyu dan mengetahui konteksnya, serta memahami secara alamiah struktur bahasa dan kosa katanya. Tidak jarang mereka berbeda pendapat atau bahkan keliru memahami maksud firman Allah dengan yang mereka baca. Maka muncullah sebuah alat pembantu untuk memahami ayat-ayat al-Qur'an yang bernama tafsir al-Qur'an. Tafsir ini merupakan alat bantu yang sangat membantu muslim untuk memahami kitab suci al-Qur'an dengan baik.

Di balik keistimewaan ilmu tafsir yang dapat mempermudah manusia untuk memahami alQur'an dengan baik dan benar, terdapat beberapa hal yang juga dapat menjerumuskan pembaca dan peminatnya pada kesalahan yang jauh menyimpang dari syari'at. Hal ini disebabkan karena banyaknya riwayat-riwayat israiliyyat yang masuk ke dalam tafsir al-Qur'an.

Kehadiran israiliyyat dalam penafsiran al-Qur'an juga menjadi polemik dikalangan para ahli tafsir al-Qur'an. Karenanya, kita harus mengetahui dan membedakan penafsiran ayat-ayat al-Qur'an yang benar agar kita tidak salah dalam memahami kitab suci al-Qur'an yang merupakan sumber utama syariat islam.

\section{PEMBAHASAN}

\section{A. Pengertian Israiliyyat}

Banyak pengertian israiliyyat yang diungkapkan oleh para ulama Ulumul Qur'an. Dan berikut beberapa diantara sekian pengertian tersebut. Ditinjau dari segi bahasa kata israiliyyat adalah bentuk jamak dan kata israiliyah, bentuk kata yang dinisbahkan pada kata Israil yang berasal dari bahasa Ibrani, Isra bararti hamba dan Il berarti Tuhan, jadi Israil adalah hamba Tuhan. Dalam deskreptif histories, Israil barkaitan erat dengan Nabi Ya'kub bin Ishaq bin Ibrahim as, dimana keturunan beliau yang berjumlah dua betas disebut Bani Israil. Di dalam al-Qur'an banyak disebutkan tentang Bani Israil yang dinisbahkan kepada Yahudi.1

Secara istilah para ulama berbeda pendapat dalam mendefinisikan israiliyyat. Menurut adzDzahabi israiliyyat mengandung dua pengertian yaitu, yaitu: kisah dan dongeng yang disusupkan dalam tafsir dan hadits yang asal periwayatannya kembali kepada sumbernya yaitu Yahudi, Nashrani dan yang lainnya. Selain itu, Israiliyyat merupakan cerita-cerita yang sengaja diseludupkan oleh musuh-musuh Islam ke dalam tafsir dan hadits yang sama sekali tidak dijumpai dasarnya dalam sumber-sumber lama.2

1 Muhammad Husain adz-Dzahabi, al-Israilyyat fit-Tafsiri wa al-Hadits, terjemahan Didin Hafiduddin (Jakarta, PT. Litera Antara Nusantara, 1993), h. 8.

2 Muhammad Husin adz-Dzahabi, al-Israilyyat fit-Tafsiri wa al-Hadits, terjemahan Didin Hafiduddin (Jakarta, PT. Litera Antara Nusantara, 1993), h. 9-10. 
Definisi lain dari asy-Syarbasi adalah kisah-kisah dan berita berita yang berhasil diselundupkan oleh orang-orang Yahudi ke dalam Islam. Kisah-kisah dan kebohongan mereka kemudian diserap oleh umat Islam, selain dari Yahudi merekapun menyerapnya dari yang lain.3

Sedangkan Sayyid Ahmad Khalil mendefenisikan Israiliyyat dengan riwayat-riwayat yang berasal dari ahli kitab, baik yang berhubungan dengan agama mereka maupun yang tidak ada hubungannya sama sekali dengannya. Penisbahan riwayat israiliyyat kepada orangorang Yahudi karena para perawinya berasal dari kalangan mereka yang sudah masuk Islam.4

Dari beberapa definisi yang telah dikemukan diatas, para ulama bersepakat bahwa yang menjadi pengertian Israiliyyat adalah Yahudi dan Nashrani dengan penekanan Yahudilah yang nebjadi sumber utamanya sebagaimana yang sering kita dengarkan bahwa Yahudi tercermin dari Israiliyyat itu sendiri.

Meskipun Israiliyyat banyak diwarnai oleh kalangan Yahudi, kaum Nashrani juga turut ambil bagian dalam versi penafsiran israiliyyat ini. Hanya saja dalam hal ini, kaum Yahudi lebih popular dan dominan. Karenanya kata Yahudi lebih dimenangkan lantaran selain Yahudi lebih lama berinteraksi dengan umat Islam, dikalangan mereka juga banyak yang masuk Islam. Pengaruh Israiliyyat tidak begitu membahayakan akidah Umat Islam karena umumnya hanya menyangkut urusan akhlak, nasihat dan pembersihan jiwa.

\section{B. Jenis-Jenis Israiliyyat}

Israiliyyat memiliki beberapa macam yang didasarkan pada dua tinjauan. Israiliyyat apabila ditinjau dari syariat Islamiyah, dibagi menjadi tiga macam, yaitu:

1. Kisah yang dibenarkan oleh Islam atau Khabariyah al Shidqu: Israiliyyat yang bisa dibenarkan isinya, yaitu apabila isinya sesuai dengan kandungan al-Qur'an dan sunah Nabi.

2. Kisah yang diingkari oleh Islam dan dipersaksikan bahwa kisah tersebut adalah dusta atau Khabar al-Kidzbu: Israiliyyat yang jelas isinya bertentangan dengan Al-Qur'an dan sunah atau jelas kebohongannya dan kekhurafatannya. Maka ini adalah bathil.

3. Kisah yang Islam tidak membenarkan tidak pula mengingkarinya atau Khabar al Shidqu Wal Kidzbu: Israiliyyat yang tidak diketahui benar atau tidaknya. Yang seperti ini tidak perlu diyakini atau didustakan dan kita wajib mendiamkannya.

Sedangkan israiliyyat apabila ditinjau dari riwayat cerita Israiliyyat terbagi menjadi dua, yaitu: Cerita shahih dan cerita dhaif.

\section{Sejarah Munculnya Israiliyyat}

Israiliyyat berusaha memahami al-Qur'an yang mereka anggap sebagai kelanjutan dari katabkitab mereka sebelumnya taurat dan ijnil dan didalam al-Qur'an terdapat kisah-kisah sebagian yang

3 Rosihan Anwar, Melacak Unsur-unsur Israiliyyat dalam Tafsir ath-Thabari dan Tafsir Ibnu Katsir, (Bandung: Pustaka Setia, 1999), h. 24-25.

4 Sayyid Kamal Khalil, Dirasah fil al-Qur'an, (Mesir: Dar al-Ma'rofah, 1961), h.113. 
tertulis dalam Kitab mereka. Kisah Israiliyyat dalam tafsir al-Qur'an tidak lepas dari kondisi kultur masyarakat Arab dan zaman jahiliyah, sehingga keseharian mereka tidak dapat dihindari adanya interaksi kebudayaan Yahudi dan Nashrani dengan kebudayaan Arab yang kemudian menjadi jazirah Islam.

Sejak tahun $70 \mathrm{M}$ terjadi imigrasi besar-besaran orang Yahudi ke Jazirah Arab karena adanya ancaman dan siksaan dari penguasa Romawi yang bernama Titus. Mereka pindah bersama dengan kebudayaan yang mereka dari ambil dari Nabi dan Ulama mereka, serta diwariskan dari generasi ke generasi. Mereka mempunyai tempat yang bernama Midras sebagai pusat pengajian kebudayaan warisan yang telah mereka terima dan menemukan tempat tertentu sebagai tempat beribadah dan menyiarkan agama mereka.5

Bangsa Arab suka berpindah-pindah sehingga kearah timur maupaun barat, sehinnga orang Yahudi bisa bertentangga dengan kaum muslim dan terjadi pertukaran ilmu pengetahuan. Rasulullah menemui orang Yahudi dan ahli kitab lainnya untuk mendakwahkan Islam. Orang Yahudi sendiri sering datang kepada Rasulullah saw untuk menyelesaikan suatu problem yang ada pada mereka, atau sekedar untuk mengajukan suatu pertanyaan.

Pada masa Rasulullah saw, informasi dari kaum Yahudi dikenal sebagai Israiliyah tidak berkembang dalam penafsiran al-Qur'an, sebab hanya beliau sebagai penjelas berbagai masalah atau pengertian yang berkaitan dengan ayat-ayat al-Qur'an baik makna atau kandungannya, merekapun langsung bertanya kepada Rasulullah saw.6 Kendatipun demikian,, Rasulullah juga telah memberikan semacam tanda pada umat Islam untuk menerima informasi dari Bani Israil, hal ini tampak dalam hadits beliau:

"Sampaikanlah yang datang dariku walaupun satu ayat, dan ceritakan (apa yang kamu dengar) dari Bani Israil dan hal itu tidak ada salahnya. Barang siapa yang berdusta ayatku, maka siapsiaplah untuk menempati tempatnya di neraka".

Israiliyyat sebenarnya telah muncul dan berkembang di kalangan bangsa Arab jauh sebelum Rasulullah saw, yang kemudian terus bertahan pada era Rasulullah Saw. Hanya saja ia belum menjadi khasanah yang sampai penafsiran al-Qur'an. Setelah Rasul wafat, tidak seorangpun yang berhak menjadi penjelas wahyu Allah. Dalam kondisi ini para sahabat mencari sumber dari hadits Rasul. Apabila mereka tidak menjumpai, mereka berijtihad. Riwayat dan ahli Kitab menjadi salah satu rujukan. Hal ini terjadi karena ada persamaan antara al-Qur'an, Taurat dan Injil. Hanya saja al-Qur'an berbicara secara padat, sementara Taurat dan Injil berbicara panjang lebar. Dan Israiliyyat terus berkembang pada masa sahabat dan terus berlanjut pada masa tabi'in.

5 Muhammad Husin adz-Dzahabi, al-Israilyyat fit-Tafsiri wa al-Hadits, terjemahan Didin Hafiduddin, (Jakarta, PT. Litera Antara Nusantara, 1993), h. 25.

6 Zainal Hasan Rifai, Kisah-kisah Israiliyyat dalam Penafsiran al-Qur'an dalam Belajar Ulumul Qur'an, (Jakarta: Lentera Basitama, 1992), h. 278. 
Terdapat Kitab-kitab tafsir Israiliyyat yang muncul yaitu, Jāmi'ul Bayān fî Tafsir al-Qur'an: Tafsir ini disusun oleh Ibnu Jarir al-Thabariy (224-310), seorang yang dikenal faiq, mufassir, dan ahli dalam berbagai disiplin ilmu. Disebut-sebut sebagai Tafsir yang paling unggul dalam tafsir bilma'tsur. Paling shahih dan terkumpul di dalamnya pernyataan para sahabat dan tabi'in. Tafsir ini dianggap sebagai referensi utama para mufassir. Dan Tafsir Muqatil: Disusun oleh muqatil bin Sulaiman wafat tahun $150 \mathrm{H}$. Dikenal sebagai ahli tafsir. Beliau banyak mengambil hadis dari Mujahid, Atha bin Rabah. Dhahak, dan Atiyyah. Tafsir karya Muqatil terkenal sebagai tafsir yang dengan cerita-cerita Israiliyyat tanpa memberi sanad sama sekali. Disamping itu tidak ditemukan komentar penelitian dan penjelasannya, mana yang hak dan yang batil.

\section{Pendapat Ulama Tentang Israiliyyat}

Para ulama, khususnya ahli tafsir berbeda pendapat mengenai sikap terhadap Israiliyyat ini. Diantara perbedaan-perbedaan pendapat tersebut adalah sebagai berikut:7

1. Di antara mereka ada yang memperbanyak berbicara tentangnya dengan dirangkai dengan sanad-sanadnya. Pendapat ini berpandangan bahwa dengan menyebut sanadnya, berarti ia telah berlepas diri dari tanggung jawab atasnya. Hal ini seperti yang dilakukan oleh Ibn Jarir athThabari.

2. Di antara mereka ada yang memperbanyak berbicara tentangnya dan biasanya menanggalkan sama sekali sanad-sanadnya. Ini seperti pencari kayu bakar di malam hari. Cara seperti ini dilakukan al-Baghawi di dalam tafsirnya yang dinilai oleh Syaikhul Islam Ibn Taimiyah sebagai ringkasan dari tafsir al-Tsa'alabi.Hanya saja, al-Baghawi memproteksinya dari dimuatnya hadits-hadits palsu dan pendapat-pendapat yang dibuat-buat. Syaikhul Islam Ibn Taimiyah menyebut al-Tsa'alabi sebagai seorang pencari kayu bakar di malam hari di mana ia menukil apa saja yang terdapat di dalam kitab-kitab tafsir baik yang shahih, dha'if mau pun yang maudhô' (palsu).

3. Di antaranya mereka ada yang banyak sekali menyinggungnya dan mengomentari sebagiannya dengan menyebut kelemahannya atau mengingkarinya atau meriwayatkan kisah-kisah ini lalu ada ulama yang mengkritik sebagian riwayatnya bahwa itu dhaif atau mungkarseperti yang dilakukan Ibn Katsir.

4. Di antara mereka ada yang berlebih-lebihan di dalam menolaknya dan tidak menyebut sesuatu pun darinya sebagai tafsir al-Qur'an seperti yang dilakukan Muhammad Rasyid Ridha.

\section{KESUMPULAN}

Dari uraian diatas kita bisa mengambil kesimpulan bahwasanya pengaruh israiliyyat terhadap ilmu Tafsir adalah untuk memahami al-Qur'an. Karena itu tafsir al-Qur'an mempunyai peranan yang sangat besar. Namun, ilmu tersebut akan menjadi sesuatu yang tidak berharga lagi ketika

7 Ozekage's Blog, "Makalah Israiliyat" WordPress.com, 7 Februari 2013.http://ozekage.wordpress.com/2013/02/07/makalah-israiliyat/ (29 disember2013) 
terkontaminasi dengan hal yang merusak keabsahan dan kebenarannya,dan akan merusak bagi kalangan yang awam yang tidak mengetahuinya.

Masuknya israiliyyat dalam tafsir tidak terlepas dari kondisi sosio kultrul masyarakat arab pada zaman jahiliyah. Adanya migrasi besar besaran orang Yahudi pada tahun $70 \mathrm{M}$ ke jazirah Arab karena ancaman dari Romawi yang dipimpin oleh kaisar Titus menimbulkan kontak antara keduanya, ditambah lagi kondisi orang Arab sendiri yang sering melakukan perjalanan dagang ke Syam dan Yaman, di Madinah sendiri banyak orang Yahudi yang bermukim di sana.

Keberadaan Israiliyyat dalam tafsir banyak memberikan pengaruh buruk, sikap teliti yang diperlihatkan oleh para sahabat dalam mentransfer. Israiliyyat tidak menjadi perhatian genarasi sesudahnya, sehingga banyak israiliyyat yang mengandung khurafat dan bertentangan dengan nash mewarnai kitab tafsir.

\section{DAFTAR PUSTAKA}

Anwar, Rosihan. Melacak Unsur-unsur Israilliyat dalam Tafsir at-Tabrani dan Tasir Ibnu Katsir, Bandung: Pustaka Setia, 1999.

Al-Żahabī, Muhammad Husainal. Israiliyyat Tafsir al-Hadits, terjemahan Didin Hafiduddin, Jakarta;PT Litera Antara Nusantara, 1993.

Khalil, Sayyid Kamal. Dirasah Fi al-Qur'an, Mesir: Daarul Ma'rifah 1961.

Ozekage's Blog, "Makalah Israiliyyat" Word Press.com, 7 Februari 2013.http://ozekage.wordpress.com/2013/02/07/makalah-israiliyyat/ (29 Desmber 2013).

Rifai, Zainal Hasan. Kisah-kisah Israiliyyat dalam Penafsiran al-Qur'an dalam Belajar Ulumul Qur'an, Jakarta: Lentera Basitama, 1992. 